\title{
On two closely related wolf spider species Alopecosa beckeri (Thorell, 1875) and A. taeniopus (Kulczyński, 1895) (Aranei: Lycosidae)
}

\author{
Ава близких вида пауков-волков Alopecosa beckeri (Thorell, 1875) \\ и A. taeniopus (Kulczyński, 1895) (Aranei: Lycosidae)
}

\author{
Anton A. Nadolny, Mykola M. Kovblyuk \\ А.А. Надольный, Н.М. Ковблюк
}

Zoology Department, V.I. Vernadsky Taurida National University, 4 Yaltinskaya str., Simferopol 95007, Ukraine. E-mail: nadolnyanton@mail.ru, kovblyuk@mail.ru

Кафедра зоологии Таврического национального университета им. В.И.Вернадского, ул. Ялтинская 4, Симферополь 95007, Украина.

KEY WORDS: spiders, Alopecosa, redescriptions, spatial distribution, phenology, Crimea.

КЛЮЧЕВЫЕ СЛОВА: пауки, Alopecosa, переописания, ландшафтное распределение, фенология, Крым.

ABSTRACT. Redescriptions of two closely related species Alopecosa beckeri and A. taeniopus are provided based on specimens from Crimea. Comparative illustrations, diagnoses, spatial distribution, seasonal dynamic of activity for each species are presented. Distribution of $A$. beckeri presumably is limited by Crimean Mountains, and this species is endemic of Crimea probably. The earlier Crimean records of $A$. mariae and $A$ striatipes are most possible misidentifications of $A$. taeniopus.

РЕЗЮМЕ. По экземплярам из Крыма переописаны близкие и трудно различимые виды Alopecosa beckeri и A. taeniopus. Для обоих видов приведены сравнительные рисунки, дифференциальный диагно3, распределение по ландшафтным зонам Крыма и сезонная динамика активности половозрелых особей. Предполагается, что A. beckeri распространён исключительно в Крымских горах, и что этот вид эндемик Крыма. Указания из Крыма видов A. mariae и A striatipes, вероятно, результат ошибочного определения $A$. taeniopus.

\section{Introduction}

The genus Alopecosa Simon, 1885, contains 160 species, mostly from the Palaearctic [Platnick, 2010]. So far 13 species have been reported from Crimea [Kovblyuk, 2004]: A. accentuata (Latreille, 1817), A. beckeri (Thorell, 1875), A. cronebergi (Thorell, 1875), A. cursor (Hahn, 1831), A. inquilina (Clerck, 1758), A. mariae (F. Dahl, 1908), A. pentheri (Nosek, 1905), A. pulverulenta (Clerck, 1758), A. schmidti (Hahn, 1835), A. solitaria (Hermann, 1879), A. sulzeri (Pavesi, 1873), A. taeniopus (Kulczyński, 1895) and $A$. trabalis (Clerck, 1758). Some of them are poorly known, or their records are doubtful. For example, A. beckeri is known after the original description by Thorell [1875a] with- out illustrations, and A. taeniopus was recorded by Spassky [1927] only once. Absence of redescriptions and any illustrations of $A$. beckeri and its similarity in copulatory organs to $A$. taeniopus, is making these species difficult to distinguish. Study of syntypes of $A$. beckeri in Swedish Museum of Natural History (Stockholm), and specimens newly collected in Crimea, has confirmed the presence of these two closely related species in Crimea, and the lack in Crimea any other related species (A. mariae for example).

The aim of article is to provide redescriptions of $A$. beckeri and $A$. taeniopus, and also to provide information about the spatial distribution and seasonal dynamics of activity of adults in Crimea.

\section{Material and Methods}

Syntypes of $A$. beckeri were examined by M.K. in the Swedish Museum of Natural History (Stockholm) in 2004 courtesy of T. Kronestedt. Drawings and photos of the male palp and female epigyne of syntypes of A. beckeri were examined courtesy of Yu.M. Marusik and T. Kronestedt. Specimens of $A$. beckeri and $A$. taeniopus from Crimea for this study were recently collected by M.K., mostly by pitfall traps. Specimens of A. taeniopus from Belgorod and Rostov Areas of Russia from collection A.V. Ponomarev (Rostov-onDon) were examined as comparative material.

Following abbreviations have been used in text: SMNH - Swedish Museum of Natural History (Stockholm); TNU - collection Zoology Department, V.I. Vernadsky Taurida National University (Simferopol); a - apical; d - dorsal; pl - prolateral; rl - retrolateral; v - ventral. Abbreviations on figures: tg.ap tegular apophysis; $p$ - palea; $e-$ embolus.

Illustrations were made using reflecting and transmitted light microscopes. Illustrations of epigynes were made after maceration in $\mathrm{KOH} 20 \%$ water solution. 

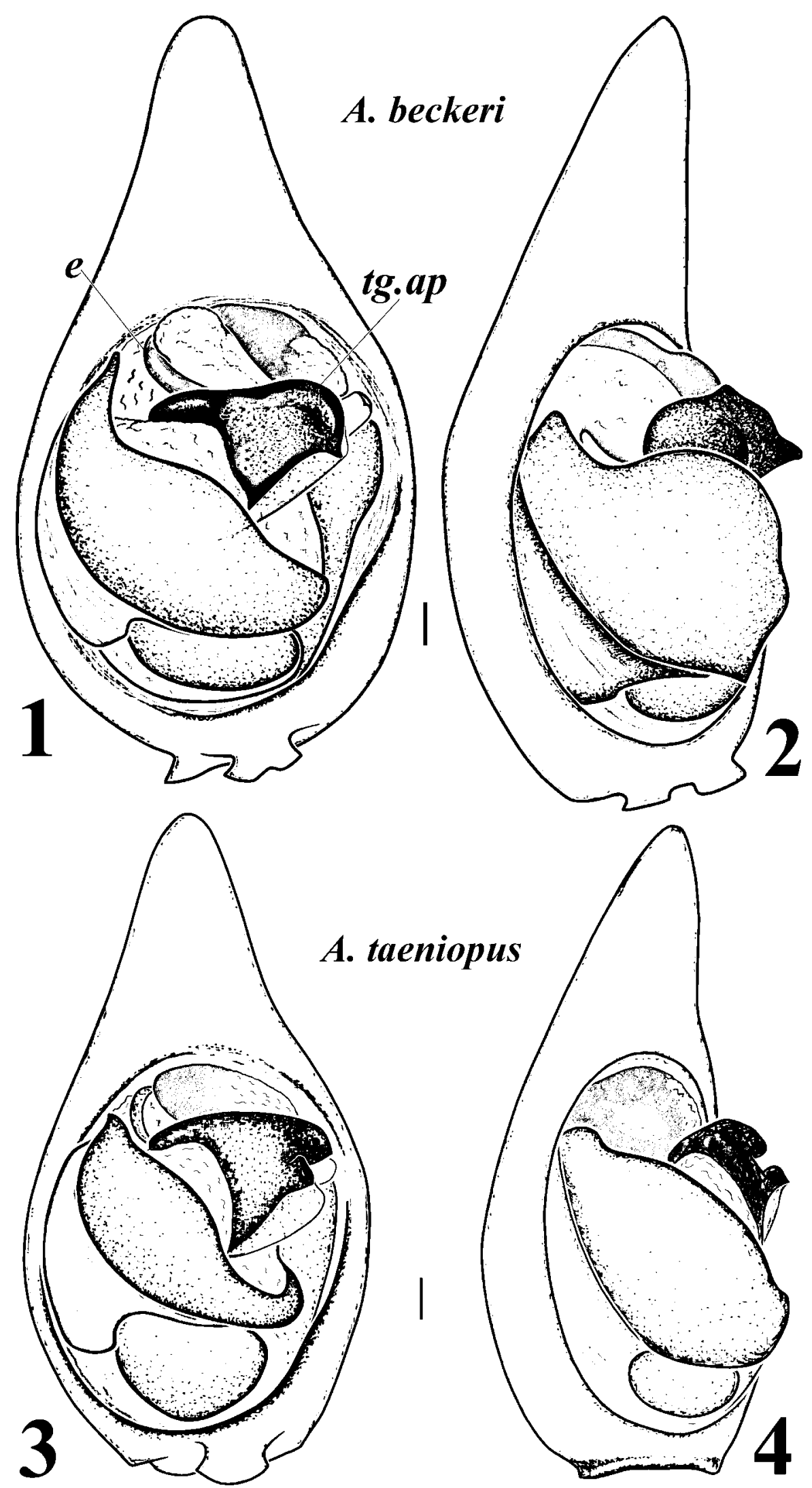

Figs 1-4. Male palps of Alopecosa beckeri (1-2) and A. taeniopus (3-4): 1, 3 - ventral view; 2, 4 - prolateral view. Рис. 1-4. Пальпы самцов Alopecosa beckeri (1-2) и A. taeniopus (3-4): 1, 3 - вентрально; 2, 4 - пролатерально. 
Coloration was described from specimens preserved in $75 \%$ ethanol/water solution with added glycerin ( $9: 1$ by volume). Legs and palps segments were measured after their separation from the cephalothorax. All measurements are in $\mathrm{mm}$. All scale bars are equal $0.1 \mathrm{~mm}$.

\section{Species survey}

\author{
Alopecosa beckeri (Thorell, 1875) \\ Figs 1-2, 5-6, 9-10, 13-16, 21, 23-24, \\ 27-28, 31-35.
}

\section{Tarentula $b$. Thorell, 1875a: 104 (○ㅇ). \\ Tarentula b.: Thorell, 1875b: 151 ( ( $\left.\sigma^{\top}+\right)$.}

Lycosa b.: Schmidt, 1895: $454\left(\sigma^{7}\right)$.

RECORDS FROM CRIMEA. Thorell, 1875a - sub Tarentula b. sp.n.; Schmidt, 1895 - sub Lycosa; Reimoser, 1919 - sub Tarentula; Charitonov, 1932; Tyshchenko, 1971; Mikhailov, 1997; Kovblyuk, 2002 — sub Tarentula; Kovblyuk, 2004a.

MATERIAL. UKRAINE. Crimea: Syntypes $1 \sigma^{7}, 1$ q (SMNH, Collectio Thorell, No. 232/1452, 233/1452), Yalta, leg. A. von Nordmann. Alushta Distr.: $1 \sigma^{T}$ (TNU), Alushta, 13.01.2001, E.Yu. Sviridenko; 2 우 (TNU), Chatyr-Dagh Mt., Eklizi-Burun Mt., S slope, $1100 \mathrm{~m}, 10.03 .2008$, A.A. Nadolny; Bakhchisaray Distr.: 4 $\sigma^{7} \sigma^{7}, 1$ क (TNU), Ay-Petry Yaila, $17 \mathrm{~km} \mathrm{~N}$ from Visokogornoe Vil., 8-9.09.1999, M.M. Kovblyuk; Simferopol Distr.: $13 \sigma^{7} \sigma^{7}, 9$ 우 (TNU), NE slope of Chatyr-Dagh Mt., 29.03.2000, M.M. Kovblyuk; 2 우 (TNU), NNW slope of Chatyr-Dagh Mt., 12.04.2000, M.M. Kovblyuk; $7 \sigma^{7} \sigma^{7}, 3$ + 9 (TNU), E slope of Chatyr-Dagh Mt., 13.05.2000, M.M. Kovblyuk; $1 \sigma^{\top}, 1$ (TNU), Chatyr-Dagh Yaila, 4.11.2000, M.M. Kovblyuk \& O.V. Kukushkin; $5 \sigma^{\top} \sigma^{\top}, 8$ 우 (TNU), Chatyr-Dagh Mt., Orlinoe Gorge, pitfalls, 8.04-18.11.2000, 17.03.2002, M.M. Kovblyuk; Sudak Distr.: 3 우 (TNU), between Shelkovichnoe and Veseloe Vil., 26.05.1998, M.V. Onchurov; Yalta Distr.: 1 (TNU), environs Yalta, 9-10.09.1999, M.M. Kovblyuk; $1 \sigma^{7}$ (TNU), Yalta Mountain-Forest Nature Reserve, Yaltinskaya Yaila Mt., over Uch-Kosh Gorge, 16.04.2000, G.A. Prokopov; 1 $\mathrm{O}^{7}, 1$ ㅇ (TNU), Martyan Cape Reserve, pitfalls, 25.03-30.04.2000, M.M. Kovblyuk; 1 ऽ (TNU), Martyan Cape Reserve, pitfalls, 1024.03.2001, M.M. Kovblyuk; $5 \sigma^{7} \sigma^{\top}, 1$ (TNU), Yalta, Massandra park, pitfalls, 24.12.2000-15.04.2001, M.M. Kovblyuk; $8 \sigma^{\top} \sigma^{7}, 2$ ${ }_{+}$(TNU), Martyan Cape Reserve, pitfalls, 19.02.2000-17.04.2001, M.M. Kovblyuk; $1 \sigma^{\top}, 1$ ( $(\mathrm{TNU})$, same locality, 10.03-29.04.2001, M.M. Kovblyuk; 1 क (TNU), Crimean State Nature Reserve, environs of kordon Asport, 13.06.2001, M.M. Kovblyuk; $3 \sigma^{\top} \sigma^{\top}, 3$ 우 (TNU), Yalta Mountain-Forest Nature Reserve, Yaltinskaya Yaila Mt., Iograf-Bogaz Gorge, 9.09.2001, M.M. Kovblyuk; 1 o (TNU), Ay-Petry Mt., 16.09.2001, A.A. Khaustov; 1 ㅇ (TNU), Ay-Petry Yaila, Kilse-Burun Mt., 14.10.2001, M.M. Kovblyuk; $107 \sigma^{7} \sigma^{7}$ 51 우 (TNU), $1 \mathrm{~km} \mathrm{~N}$ from Nikita, pitfalls, 8.01.2000-3.03.2007, M.M. Kovblyuk \& A.A. Khaustov; $1 \Im^{7}$ (TNU), Yalta MountainForest Nature Reserve, Yalta Yaila Mt., 1.05.2002, A.A. Khaustov; $1 \mathrm{O}^{7}, 5$ 우 (TNU), Yalta, 27.10.2002, A.A. Khaustov; 1 q (TNU), Ay-Petry Mt., $1200 \mathrm{~m}$ a.s.1., 5-6.10.2003, O.V. Kukushkin; 15 $\sigma^{7} \bigcirc^{7}, 29$ 우 (TNU), Crimean State Nature Reserve, Nikitskaya Yaila Mt. (=Scrinita), pitfalls, 9.03.2001-26.05.2002, M.M. Kovblyuk; $50 \sigma^{\top} \sigma^{\top}, 27$ 우 (TNU), Yalta Mountain-Forest Nature Reserve,

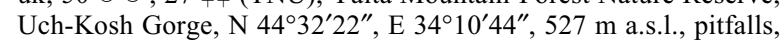
10.03-13.12.2008, M.M. Kovblyuk.

DIAGNOSIS. Male palp of $A$. beckeri is similar to that of A. taeniopus, from which it can be distinguished by not bifurcate tegular apophysis (Figs $1-2,5-6,21$ ) (bifurcate in A. taeniopus - see Figs 3-4, 7-8, 22). A. beckeri differs also from $A$. taeniopus by having an embolus not reaching the paleal edge (Figs 9-10) (in $A$. taeniopus embolus reaches paleal edge - Figs 1112). Epigyne of $A$. beckeri with straight margins and on anterior part forms the swelling (Figs 23, 27). Epigyne of A. taeniopus with curved margins, and without swelling on anterior part (Figs 25, 29). A. beckeri usually has light colored venter of abdomen (rarely dark) (Figs 33-35), but in A. taeniopus venter of abdomen is always dark (Figs 38-39). In addition these species differs slightly by body size: in $A$. beckeri male carapace 4.4-5.6 long, in female - 4.8-6.2 long; in A. taeniopus $-3.8-4.7$ and $4.2-5.1$ respectively.

DESCRIPTION. Male and female from Crimea. Measurements $\left(\sigma^{7} / 9\right)$ : total length 9.5 / 12.5; carapace 5.6 / 6.0 long, 3.5 / 4.4 wide. Length of palp segments (male/female): femur $2.1 / 2.1$, patella $1.2 / 1.2$, tibia $2.2 / 1.2$, tarsus $1.7 / 1.7$. Length of leg segments (male/ female):

\begin{tabular}{|l|c|c|c|c|c|}
\hline Leg & Femur & Patella & Tibia & Metatarsus & Tarsus \\
\hline I & $3.4 / 4.0$ & $1.8 / 2.2$ & $2.7 / 3.0$ & $2.8 / 2.8$ & $2.0 / 1.8$ \\
\hline II & $3.2 / 3.8$ & $1.8 / 2.1$ & $2.4 / 2.7$ & $2.8 / 2.8$ & $1.8 / 1.8$ \\
\hline III & $3.1 / 3.5$ & $1.6 / 1.8$ & $2.2 / 2.4$ & $3.0 / 3.2$ & $1.6 / 1.7$ \\
\hline IV & $4.0 / 4.6$ & $1.8 / 2.2$ & $3.1 / 3.6$ & $4.4 / 5.0$ & $2.0 / 2.2$ \\
\hline
\end{tabular}

Male leg spination. Femur: I - d 1-1-1, pl 1, rl 1-11; II - d 1-1-1, pl 1-1, rl 1-1-1; III - d 1-1-1, pl 1-1, rl 1-1-1; IV - d 1-1-1, pl 1-1, rl 1. Patella: I - pl 1; II - pl 1; III - pl 1, rl 1; IV — pl 1, rl 1. Tibia: I - pl 11, rl 1-1, v 2-2-2 (a); II - pl 1-1, rl 1-1, v 2-2-2 (a); III - d 1-1, pl 1-1, rl 1-1, v 2-2-2 (a); IV - d 1-1, pl 1-1, rl 1-1, v 2-2-2 (a). Metatarsus: I - pl 1-1-1 (a), rl 1-11 (a), v 2-2-3 (a); II - pl 1-1-1 (a), rl 1-1-1 (a), v 2-2-3 (a); III - pl 1-1-1 (a), rl 1-1-1 (a), v 2-2-3 (a); IV — pl 1-1-1 (a), rl 1-1-1 (a), v 2-2-3 (a).

Female leg spination. Femur: I - d 1-1-1, pl 1, rl 11; II - d 1-1-1, pl 1-1, rl 1-1; III - d 1-1-1, pl 1-1, rl 1-1; IV - d 1-1-1, pl 1, rl 1-1. Patella: II - pl 1; III pl 1, rl 1; IV - pl 1, rl 1. Tibia: I - pl 1-1, v 2-2-2 (a); II - pl 1-1, v 2-2-2 (a); III - d 1-1, pl 1-1, rl 1-1, v 22-2 (a); IV - d 1-1, pl 1-1, rl 1-1, v 2-2-2 (a). Metatarsus: I - pl 1 (a), v 2-2-3 (a); II - pl 1-1 (a), v 2-2-3 (a); III - pl 1-1-1 (a), rl 1-1-1 (a), v 2-2-3 (a); IV - pl 1-1-1 (a), rl 1-1-1 (a), v 2-2-3 (a).

Cheliceral teeth $\left(\mathrm{O}^{\mathrm{T}}+\right.$ ): anterior -3 , posterior -2 . General appearance: male - Figs 31, 33-34; female - Figs 32, 35. Abdomen more often light on venter, rarely dark (Fig 34).

Male palp: Figs 1-2, 5-6, 9-10, 13-16, 21; epigyne: Figs 23-24, 27-28.

VARIATION. Males $(n=10)$ : carapace length varies from 4.4 to 5.6, carapace width - from 3.2 to 4.0. Females $(n=10)$ : carapace length varies from 4.8 to 6.2, carapace width - from 3.7 to 4.6.

TYPE LOCALITY. Environs of Yalta, Crimea [Thorell, 1875b; label data of syntypes].

DISTRIBUTION. Crimean Mountains.

NOTE. Record A. beckeri from Sarepta (Krasnoarmeisk in Volgograd Area of Russia) [Becker, 1888; Charitonov, 1932; Mikhailov, 1997] is rather doubtful and must be referred to another, probably undescribed, species. This problem should be addressed in the future. That is why A. beckeri should be listed as species endemic for the Crimean Peninsula. 


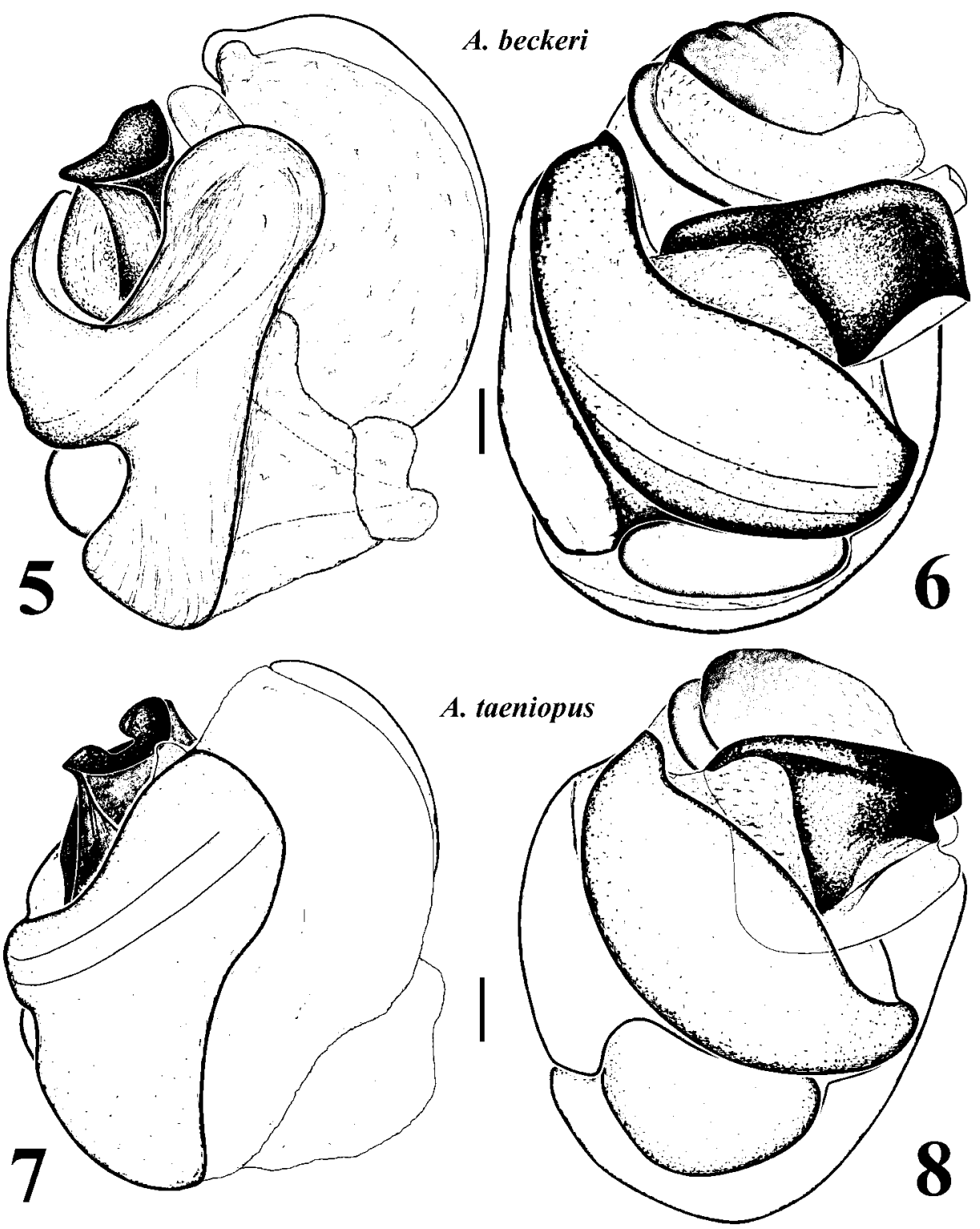

Figs 5-8. Male copulatory organs (bulbus) of Alopecosa beckeri (5-6) and A. taeniopus (7-8): 5, 7 - retrolateral view; 6, 8 - ventral view.

Рис. 5-8. Копулятивные органы самцов (бульбус) Alopecosa beckeri (5-6) и A. taeniopus (7-8): 5, 7 — ретролатерально; 6, 8 вентрально.

HABITATS. Sub-Mediterranean and mountains forests with Juniperus excelsa, J. oxycedrus, J. sabina, Pistacia mutica, Arbutus andrachne, Pinus kochiana, $P$. pallasiana, Quercus pubescens, Q. petraea, Carpinus orientalis, Carpinus betulus.

PHENOLOGY. $\sigma^{T} \sigma^{\top}-$ I-XII, $+9-$ II-XI.

Alopecosa taeniopus (Kulczyński, 1895)

Figs 3-4, 7-8, 11-12, 17-20, 22, 25-26, 29-30, 36-39.

Tarentula t. Kulczyński, 1895: 16, pl. 1, f. 6, 9 ( ( Lycosa lineatipes Nosek, 1905: 139, f. $16\left(\sigma^{7}\right)$. A. t.: Lugetti, Tongiorgi, 1969: 84, f. 24a-d (O'T).
A. $t$ : : Fuhn \& Niculescu-Burlacu, 1971: 168, f. 82a-e ( $\left.\sigma^{\top}+\right)$. A. mariae: $\mathrm{Hu} \& \mathrm{Wu}, 1989:$ 192, f. 159.1-2 (ㅇ, misidentified). A. $t$ : : Mcheidze, 1997: 219, f. 459 ().

A. $t$ : Song et al., 1999: 318, f. 188C ().

RECORDS FROM CRIMEA. Spassky, 1927; Charitonov, 1932; Tyshchenko, 1971; Mikhailov, 1997 - sub Tarentula; Kovblyuk, 2004a, 2004b - sub Tarentula; Kovblyuk et al., 2008a — misidentification $A$. beckeri; Kovblyuk et al., 2008b.

As Alopecosa mariae (F. Dahl, 1908) - misidentifications: Thorell, 1875a,b — sub Tarentula striatipes Dol.; Charitonov, 1932 and Mikhailov, 1997 — sub Tarentula; Kovblyuk, 2004.

NOTE. Thorell's records of A. striatipes from "Simferopol, Sewastopol, Alma" [Thorell, 1875a: 104] was referred by Charitonov [1932] to A. mariae. This record was based on unknown sex and number of specimens collected in Crimea by A. Nordmann. $A$. striatipes and especially $A$. mariae are very similar to $A$. taeniopus 

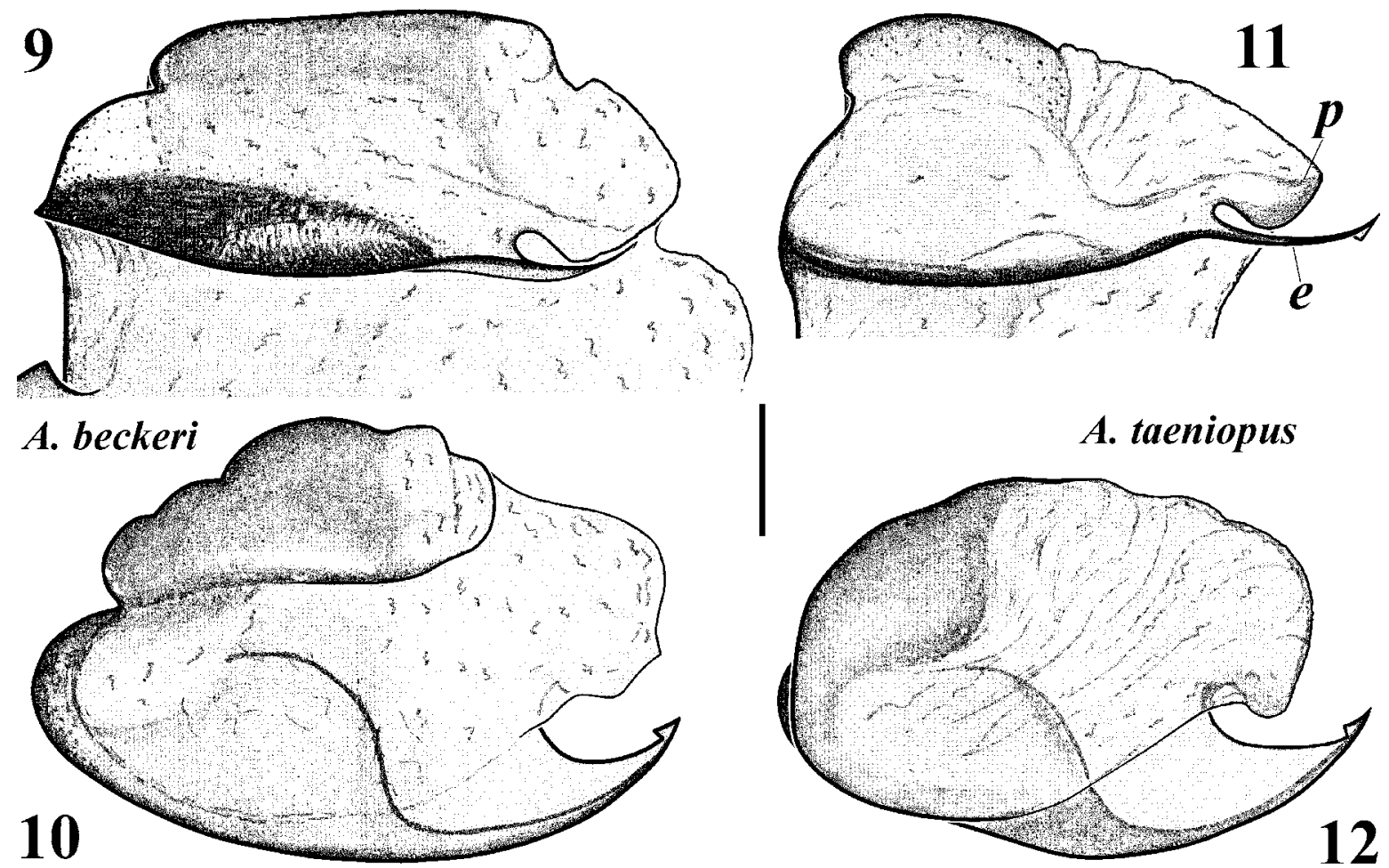

Figs 9-12. Embolic division of Alopecosa beckeri (9-10) and A. taeniopus (11-12): 9, 11 - ventral view; 10, 12 - apical view. Рис. 9-12. Эмболярный отдел Alopecosa beckeri (9-10) и A. taeniopus (11-12): 9, 11 — вентрально; 10, 12 - апикально.

[see Lugetti \& Tongiorgi, 1969]. In our material from the Crimea A. striatipes and $A$. mariae are absent. It is reasonable to conclude that the earlier records $A$. striatipes and A. mariae from the Crimea were based on misidentification of $A$. taeniopus.

MATERIAL. UKRAINE. Crimea: Bakhchisaray Distr.: 1 o (TNU), Esky-Kermen, 24.02.1996, M.M. Kovblyuk; Feodosiya Distr.: 1 (TNU), Karadagh Nature Reserve, Svyataya Mt., S slope, 12.10.2003, M.M. Kovblyuk; 1 ㅇ (TNU), same locality, Besh-Tash Mt., SE and W slope, 12.04.2004, M.M. Kovblyuk; $1 \sigma^{-7}, 19$ (TNU), same locality, Lobovoy Mt. Range, Shapka Monomaha Mt., 26-30.09.2006, O.V. Kukushkin; 1 o (TNU), same locality, near Shapka Monomaha Mt., 19.05.2008, A.A. Nadolny; 1 o (TNU), same locality, Biological Station, O.V. Kukushkin; 1 o (TNU), Feodosiya, Pasha-Tepe (=Lysaya) Mt., 2008, V.V. Savchuk. Lenin Distr. (Kerch Peninsula): $1 \sigma^{7}$ (TNU), Opuk Mt., SE slope, 6.10.1999, M.M. Kovblyuk. Saky Distr.: $880^{7} \sigma^{7}, 38$ 우 (TNU), environs of Pribrezhnaya railway station, pitfalls, 8.023.12.2000, M.M. Kovblyuk. Simferopol Distr.: $2 \mathrm{O}^{7} \mathrm{O}^{7}$ (TNU), Simferopol, 15.03., 14.04.1996, M.M. Kovblyuk; 2 우 (TNU), env. Strogonovka Vil., 16.02.1997, M.M. Kovblyuk; $20^{7} 0^{\top}, 5$ 우 (TNU), env. Krasnolesye Vil., 31.03.2000, M.M. Kovblyuk; 1 q (TNU), env. of Andrusovo Vil., pitfalls, 26.09-8.10.2000, M.M. Kovblyuk; $30 \bigcirc^{7} O^{7}, 6$ 오 (TNU), near Lozovoe, SE slope of Bairakly Mt., pitfalls, 6.02-26.11.2000, M.M. Kovblyuk; 5 O $^{7} \sigma^{7}$ (TNU), Simferopol, $1.5 \mathrm{~km} \mathrm{~N}$ from dam of Simferopol water reservoir, pitfalls, 6.02-26.11.2000, M.M. Kovblyuk; $1 \mathrm{O}^{\top}$ (TNU), env. of Strogonovka Vil., 11.02.2001, M.M. Kovblyuk; $149 \sigma^{7} \sigma^{7}, 41$ 우 (TNU), env. of Skvortsovo Vil., steppe, pitfalls, 17.02-10.07.2002, M.M. Kovblyuk; 1 \& (TNU), env. of Chysten'koe Vil., 8-9.05.2004, E.Yu. Sviridenko.

COMPARATIVE MATERIAL. RUSSIA. Belgorod Area: $10^{7}$ (TNU), $25 \mathrm{~km} \mathrm{~W}$ from Belgorod, Kustovoe Vil., steppe, 17.10.1998, A.V. Ponomarev. Rostov Area: Ust-Donetsk Distr.: $20^{7} \sigma^{7}$ (TNU), Razdorskaya Vil., steppe, 28.09-13.10.2001, A.V. Ponomarev; 7 우 (TNU), same locality, 10-30.05.2003, A.V. Ponomarev; $20^{7} \sigma^{t}$,
2 우 (TNU), Krymskyi Vil., 25.04-6.06.2005, A.V. Ponomarev; 1 $\mathrm{O}^{7}$ (TNU), Rasdorskaya Vil., steppe, 17.09.2007, M.M. Kovblyuk.

DIAGNOSIS. See the A. beckeri diagnosis.

DESCRIPTION. Male and female from Crimea. Measurements $\left(\sigma^{\top} /\right.$ ) $)$ : total length 8.7 / 10.0; carapace 4.7 / 5.0 long, 3.3 / 3.5 wide. Length of palp segments (male/ female): femur $1.8 / 1.6$, patella 0.9 / 0.9, tibia 0.8 / 0.9, tarsus 1.5 / 1.4. Length of leg segments (male/female):

\begin{tabular}{|l|l|l|l|l|l|}
\hline Leg & Femur & Patella & Tibia & Metatarsus & Tarsus \\
\hline I & $3.0 / 3.2$ & $1.6 / 1.8$ & $2.3 / 2.2$ & $2.6 / 2.2$ & $1.8 / 1.6$ \\
\hline II & $3.0 / 3.0$ & $1.6 / 1.6$ & $2.2 / 2.1$ & $2.4 / 2.2$ & $1.7 / 1.6$ \\
\hline III & $2.8 / 2.7$ & $1.4 / 1.5$ & $2.0 / 1.9$ & $2.6 / 2.4$ & $1.6 / 1.5$ \\
\hline IV & $3.4 / 3.6$ & $1.6 / 1.7$ & $2.7 / 2.8$ & $3.8 / 3.9$ & $2.0 / 2.0$ \\
\hline
\end{tabular}

Male leg spination. Femur: I - d 1-1-1, pl 1, rl 1-1; II - d 1-1-1, pl 1-1, rl 1-1; III - d 1-1-1, pl 1-1, rl 11-1; IV — d 1-1-1, pl 1-1, rl 1. Patella: I — pl 1; II pl 1; III — pl 1, rl 1; IV — pl 1, rl 1. Tibia: I — pl 1-1, rl 1-1, v 2-2-2 (a); II - pl 1-1, rl 1-1, v 2-2-2 (a); III d 1-1, pl 1-1, rl 1-1, v 2-2-2 (a); IV - d 1-1, pl 1-1, rl 1-1-1, v 2-2-2 (a). Metatarsus: I — pl 1-1-1 (a), rl 1-1 (a), v 2-2-3 (a); II — pl 1-1-1 (a), rl 1-1-1 (a), v 2-2-3 (a); III - pl 1-1-1 (a), rl 1-1-1 (a), v 2-2-3 (a); IV - pl 1-1-1 (a), rl 1-1-1 (a), v 2-2-3 (a).

Female leg spination. Femur: I - d 1-1-1, pl 1, rl 11; II - d 1-1-1, pl 1-1, rl 1-1; III - d 1-1-1, pl 1-1, rl 1-1-1; IV - d 1-1-1, pl 1-1, rl 1. Patella: III — pl 1, rl 1; IV — pl 1, rl 1. Tibia: I — pl 1, v 2-2-2 (a); II — pl 1-1, v 2-2-2 (a); III - d 1-1, pl 1-1, rl 1-1, v 2-2-2 (a); 


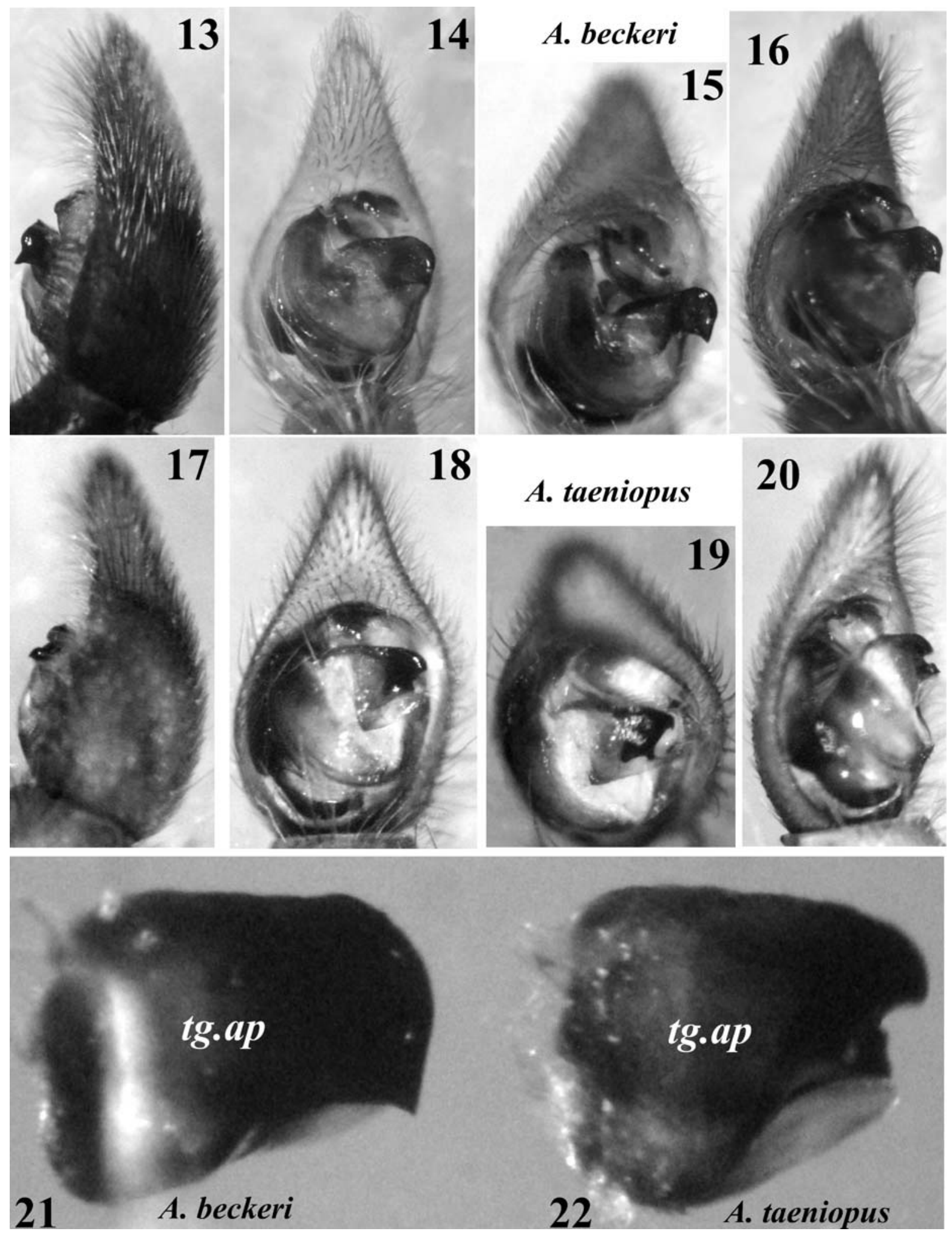

Figs 13-22. Male palps and tegular apophyses of Alopecosa beckeri $(13-16,21)$ and A. taeniopus $(17-20,22): 13,17$ - retrolateral view; 14, 18, 21-22 - ventral view; 15,19 - apical view; 16,20 - prolateral view.

Рис. 13-22. Пальпы самшов и отростки тегулюма Alopecosa beckeri $(13-16,21)$ и A. taeniopus $(17-20,22): 13,17-$ ретролатерально; 14, 18, 21-22 - вентрально; 15, 19 - апикально; 16, 20 - пролатерально. 


\section{A. beckeri}

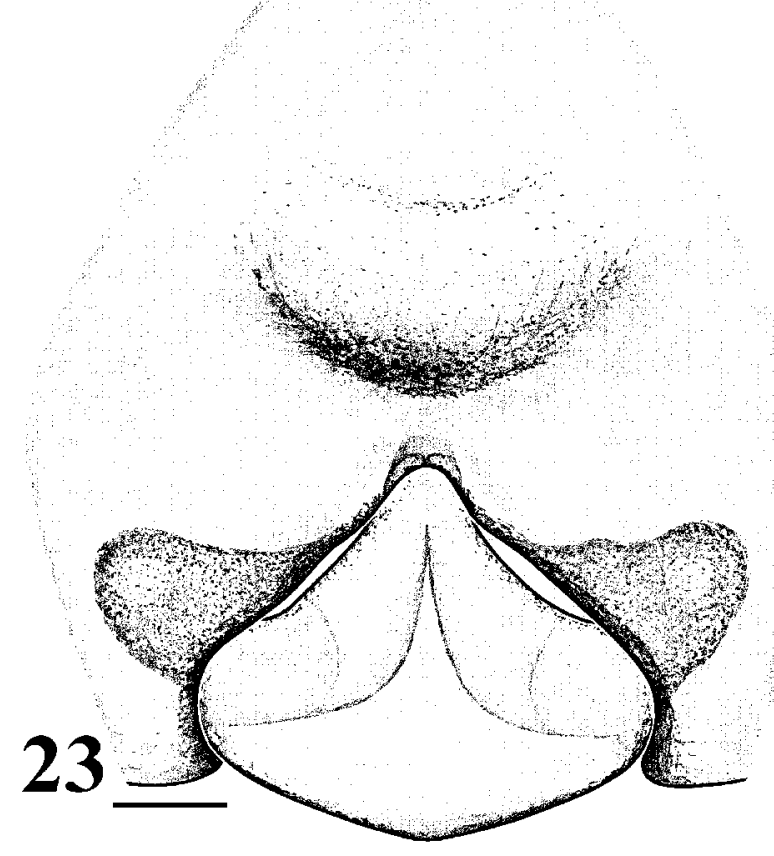

\section{A. taeniopus}
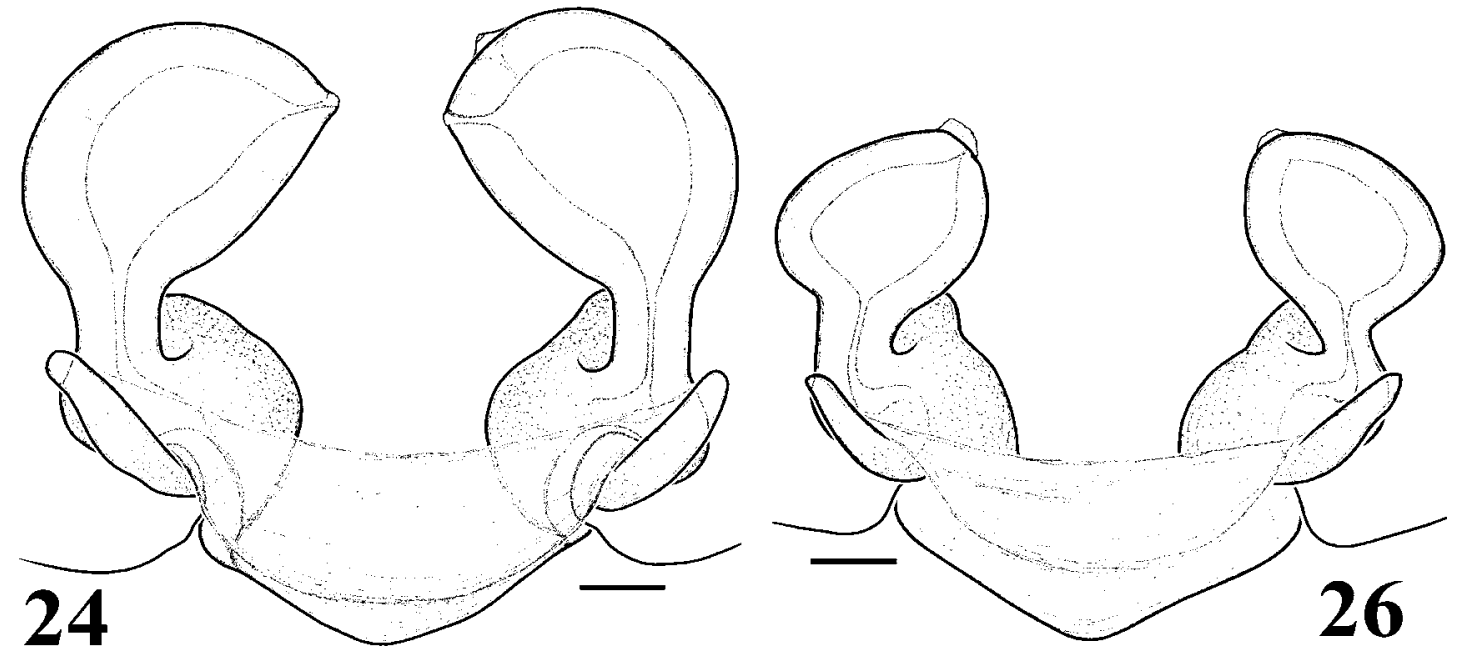

Figs 23-26. Epigynes of Alopecosa beckeri (23-24) and A. taeniopus (25-26): 23, 25 - ventral view; 24, 26 - dorsal view.

Рис. 23-26. Эпигины Alopecosa beckeri (23-24) и A. taeniopus (25-26): 23, 25 - вентрально; 24, 26 - дорсально (после мацерации).

IV - d 1-1, pl 1-1, rl 1-1, v 2-2-2 (a). Metatarsus: I pl 1 (a), v 2-2-3 (a); II — pl 1-1 (a), v 2-2-3 (a); III pl 1-1-1 (a), rl 1-1-1 (a), v 2-2-3 (a); IV — pl 1-1-1 (a), rl 1-1-1 (a), v 2-2-3 (a).

Cheliceral teeth $\left(O^{7}\right)$ : anterior -3 , posterior -2 .

General appearance: male — Figs 36, 38; female Figs 37, 39. Venter of abdomen is dark.

Male palp: Figs 3-4, 7-8, 11-12, 17-20, 22; epigyne: Figs 25-26, 29-30.

VARIATION. Males $(n=10)$ : carapace length varies from 3.8 to 4.7 , carapace width — from 2.8 to 3.3 .
Females $(n=10)$ : carapace length varies from 4.2 to 5.1, carapace width - from 3.2 to 3.8 .

TYPE LOCALITY. Georgia [Kulczyński, 1895].

DISTRIBUTION. West and Central Palaearctic nemoral range: from Bulgaria and Romania east to China (Xinjiang), north to Russian Plain (Ukraine, Belgorod Area of Russia), Middle and South Urals, West Siberia, south to Turkey, Georgia, Kazakhstan and mountainous Middle Asia [Kulczyński, 1895; Nosek, 1905; Lugetti \& Tongiorgi, 1969; Fuhn \& NiculescuBurlacu, 1971; Hu \& Wu, 1989; Esyunin \& Efimik, 

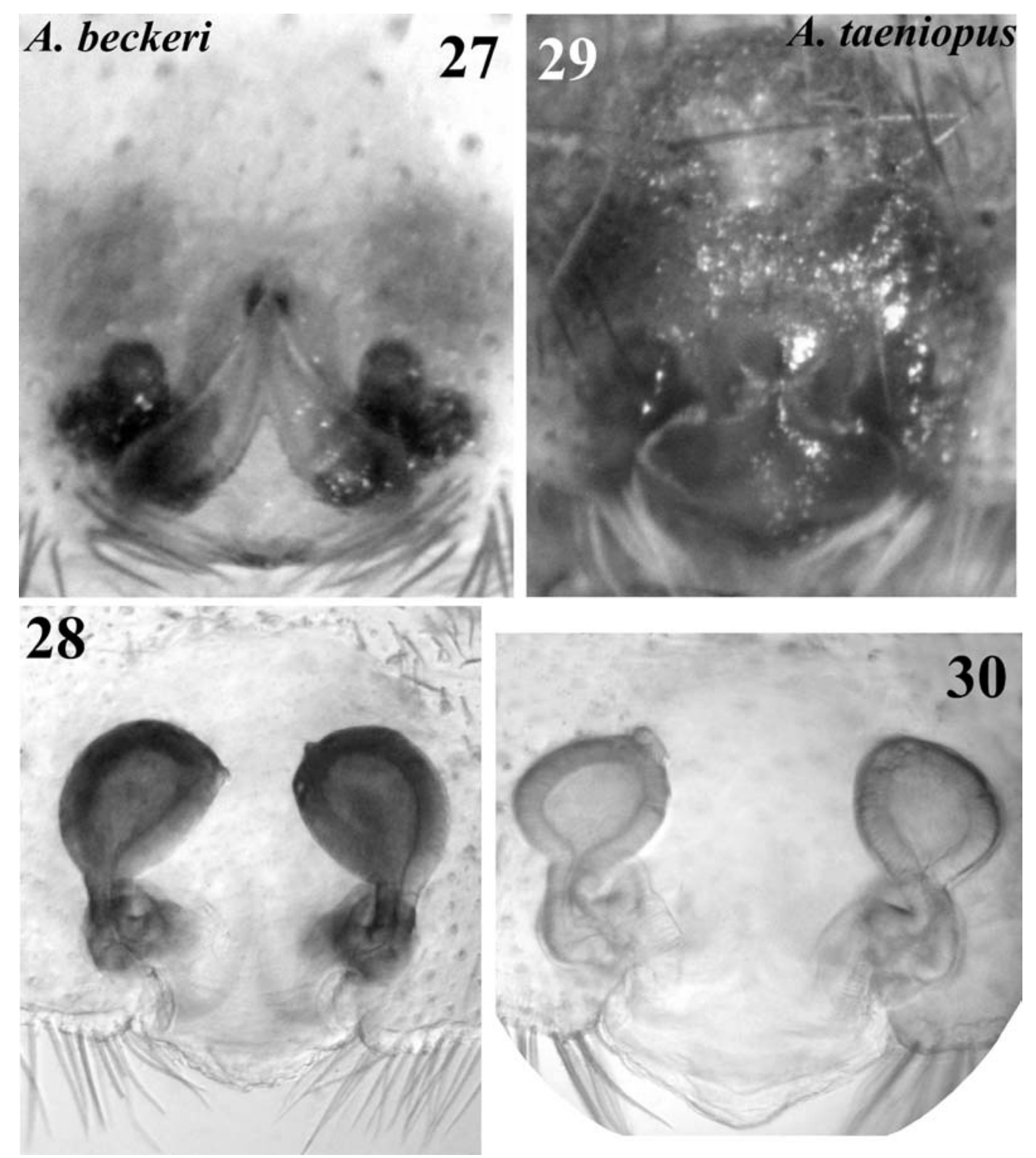

Figs 27-30. Epigynes of Alopecosa beckeri (27-28) and A. taeniopus (29-30): 27, 29 — ventral view; 28, 30 - dorsal view.

Рис. 27-30. Эпигины Alopecosa beckeri (27-28) и A. taeniopus (29-30): 27, 29 — вентрально; 28, 30 - дорсально (после мацерации).

1996; Mikhailov, 1997; Mcheidze, 1997; Song et al., 1999; Kovblyuk, 2004a].

HABITATS. Steppes with Stipa, Festuca, Asphodeline, Amygdalus nana.

PHENOLOGY. $\sigma^{\top} \sigma^{\top}-$ II-XII, + + - II-XI. In Romania $O^{\top} O$ - I-XII [Fuhn \& Niculescu-Burlacu, 1971].

\section{Spatial distribution}

Specimens of $A$. beckeri and $A$. taeniopus were found in all Crimean landscape (physical-geographic) zones. In Crimea there are seven major landscape zones: 1 - semi-desert steppe and saline lands; 2 - true steppe; 3 - premontane forest steppe; 4 - forests of
Table 1. Distribution of $A$. beckeri and A. taeniopus in the landscape zones of Crimea. Таблица 1. Ландшафтное распространение $A$. beckeri и A. taeniopus в Крыму.

\begin{tabular}{|l|c|c|}
\hline Landscape zone & A. beckeri & A. taeniopus \\
\hline $\begin{array}{l}\text { Semi-desert steppe and } \\
\text { saline lands }\end{array}$ & - & + \\
\hline True steppe & - & + \\
\hline Premontane forest steppe & - & + \\
\hline Forests of the northern slope & + & + \\
\hline $\begin{array}{l}\text { Mountain meadows and } \\
\text { yaila steppes }\end{array}$ & + & - \\
\hline Forests of the southern slope & + & + \\
\hline $\begin{array}{l}\text { Sub-mediterranean area of } \\
\text { the southern coast }\end{array}$ & + & \\
\hline
\end{tabular}



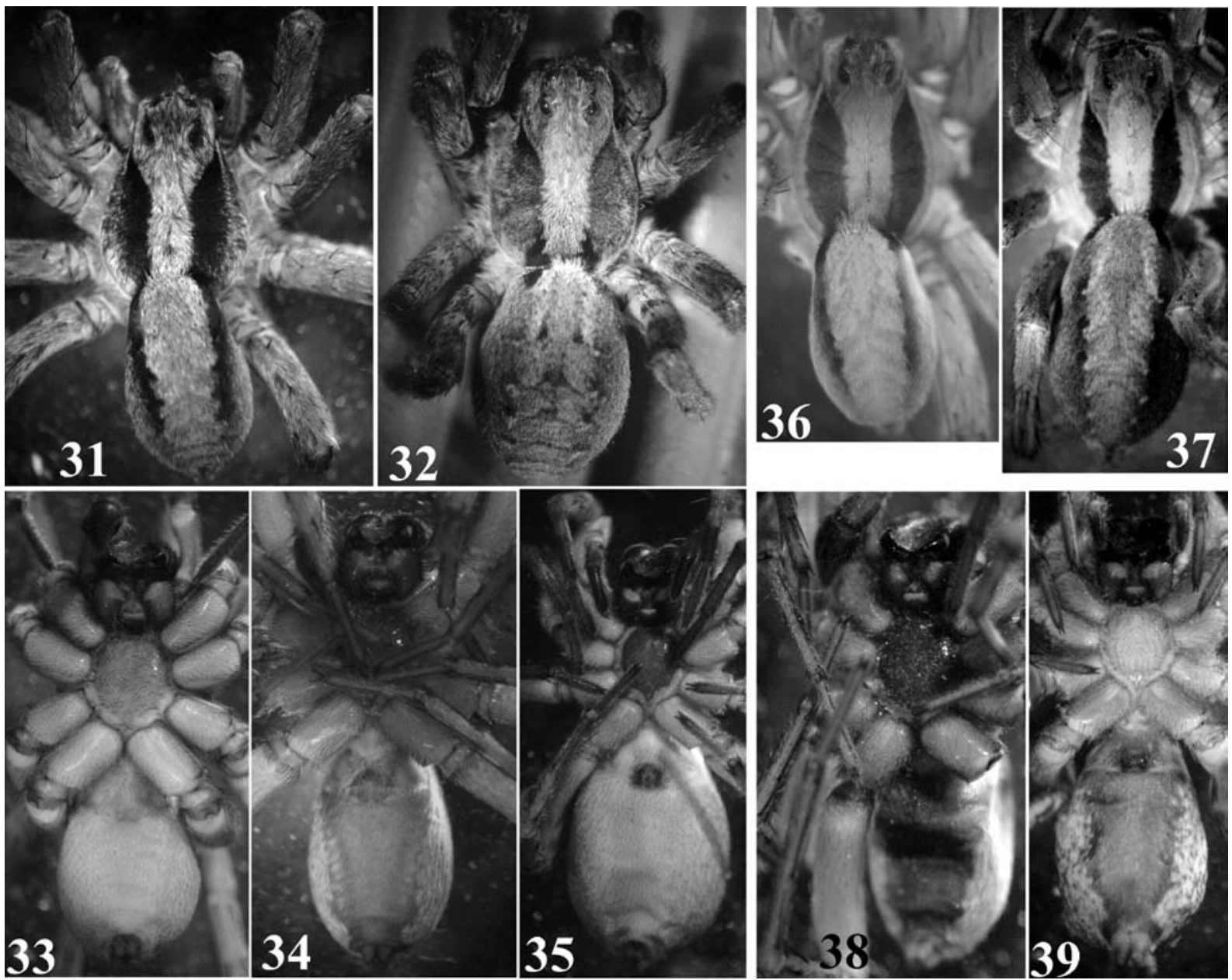

Figs 31-39. General appearance of Alopecosa beckeri (male - 31, 33-34; female - 32, 35) and A. taeniopus (male - 36, 38; female 37, 39): 31-32, 36-37 - dorsal view; 33-35, 38-39 - ventral view.

Рис. 31-39. Внешний вид Alopecosa beckeri (самец - 31, 33-34; самка - 32, 35) и A. taeniopus (самец - 36, 38; самка - 37, 39): 31-32, 36-37 - дорсально; 33-35, 38-39 - вентрально.

the northern slope of Crimean mountains; 5 - mountain meadows and steppes; 6 - forests of the southern slope of Crimean mountains; 7 - sub-Mediterranean vegetation of the Southern Coast of Crimea. Landscape distribution of $A$. beckeri and A. taeniopus is shown in Table 1 and on Map 1.

A. beckeri is recorded only from Crimean mountains (forests of the northern slope; mountain meadows and steppes, forests of the southern slope) and in subMediterranean areas of the southern coast. A. taeniopus was found in saline lands, semi-desert steppe and forest-steppe. A few specimens were found in forests of the northern slope and sub-Mediterranean areas of southern Crimea.

In conclusion, distribution of $A$. beckeri in the Crimea is limited by true mountain parts of peninsula only, but $A$. taeniopus occurs around the Crimean Mountains.

In addition, these species are differs in habitat preferences: A. beckeri occurs in forests or nearby, in con- trast to A. taeniopus, occurring in open biotopes, chiefly in steppes.

\section{Seasonal dynamic of activity}

Seasonal activities of $A$. beckeri and $A$. taeniopus are similar. Both species have 2 peaks of activity: in spring (March) and in autumn (A. beckeri - in November, $A$. taeniopus - in October). Seasonal dynamics of adults' activity show in a Fig 40.

ACKNOWLEDGMENTS. We sincerely thank T. Kronestedt (Stockholm) and Yu.M. Marusik (Magadan, Russia) for information, drawings and photos of $A$. beckeri syntypes; A.V. Ponomarev (Rostov-on-Don, Russia) for comparative material of A. taeniopus. We also thanks to A.A. Khaustov (Yalta), O.V. Kukushkin (Karadagh Nature Reserve), E.Yu. Sviridenko (Kiev), G.A. Prokopov, M.V. Onchurov (both from Simferopol) and V.V. Savchuk (Feodosiya) for providing us 


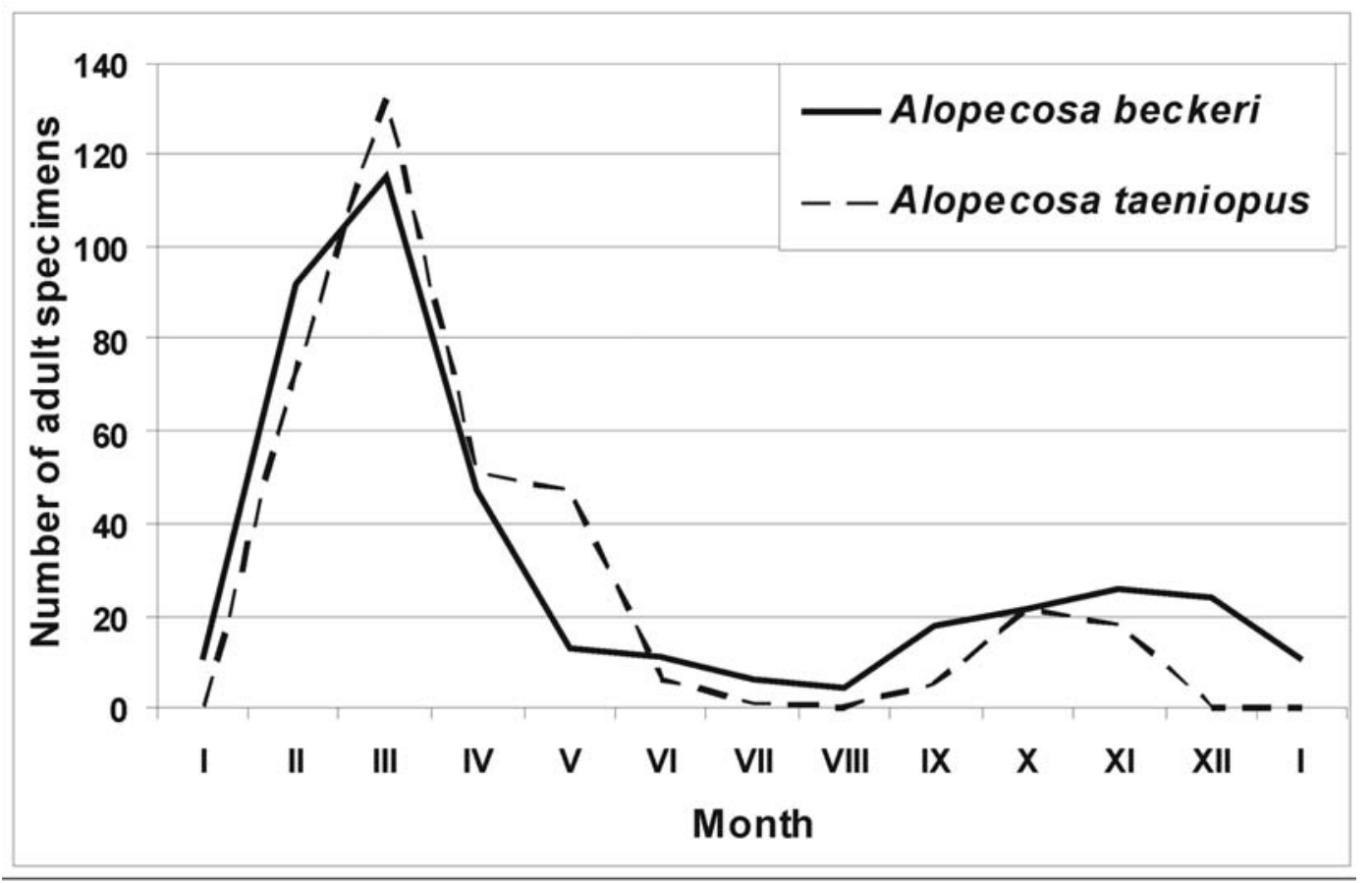

Fig. 40. Comparative phenology of Alopecosa beckeri and A. taeniopus in the Crimea, based on the specimens collected. Рис. 40. Сравнительная фенология Alopecosa beckeri and A. taeniopus в Крыму по материалам коллекции.

some spiders collected from Crimea. Authors sincerely thank Yu.M. Marusik for some important remarks and corrections. English of the final draft was checked by Robin Leech (Edmonton, Canada).

This work of M.K. was supported in part by the Karadagh Nature Reserve and Russian Foundation for Basic Research (grant \# 09-04-90900 - моб._снг_ст.).

\section{References}

Becker A. 1888. Die Spinnen und fortgesetzte Mitteilungen uber bei Sarepta vorkommende Insekten // Bull. Soc. Nat. Moscou. Nouv. ser. T.2. No.2. P.373-379. (Non Visum. Cited after Charitonov [1932] and Mikhailov [1997]).

Charitonov D.E. 1932. Katalog der russischen Spinnen. AN SSSR. Leningrad: Izdatelstvo AN SSSR. 206 S.

Esyunin S.L., Efimik V.E. 1996. Catalogue of the spiders (Arachnida, Aranei) of the Urals. Moscow: KMK Scientific Press Ltd. $229 \mathrm{p}$.

Fuhn I.E., Niculescu-Burlacu F. 1971. Arachnida. Fam. Lycosidae // Fauna Republicii Socialiste Romania. Vol.5. No.3. 256 p.

Hu J.L., Wu W.G. 1989. Spiders from agricultural regions of Xinjiang Uygur Autonomous Region, China. Jinan: Shandong University Publishing House. 435 p.

Kovblyuk M.M. 2002. [To the question about endemism of Crimea spiders (Arachnida, Aranei)] // Bioraznoobrazie na zapovednykh territoriyakh: 5 let posle Gurzufa. Materialy Vtoroi nauchnoi konferentsii (25-26 April 2002, Simferopol, Crimea). Simferopol: KGMU. P.103-109 [in Russian].

Kovblyuk M.M. 2004a. [Catalogue of the spiders (Arachnida, Aranei) of the Crimea] // Voprosy razvitiya Kryma. Vyp.15. Problemy inventarizatsii krymskoi bioty. Simferopol: Tavriya-Plus. P.211-262 [in Russian], 321 [English summary].

Kovblyuk M.M. 2004b. [Preliminary results of spiders fauna and biotopic distribution of spiders in Karadagh Nature Reserve study] // National Academy of Sciences of Ukraine. Karadagh Nature Reserve. Annals. T.20 (2003). P.139-145 [in Russian].

Kovblyuk M.M., Nadolny A.A., Gnelitsa V.A., Zhukovets E.M. 2008a. [Spiders (Arachnida, Aranei) of the Martyan Cape Reserve (Crimea, Ukraine)] // Caucasian entomological bulletin. Vol.4. No.1. P.3-40 [in Russian with English summary].

Kovblyuk M.M., Kukushkin O.V., Gnelitsa V.A., Nadolny A.A. 2008b. [Brief atlas of spiders (Arachnida, Aranei) of Karadagh Nature Reserve]. Simferopol: N. Orianda. 120 pp. [in Russian with English summary].

Kulczyński W. 1895. Araneae a Dre G. Horvath in Bessarabia, Chersoneso Taurico, Transcaucasia et Armenia Russica collectae // Termes. Fuzet. T.18. P.3-38.

Lugetti G., Tongiorgi P. 1969. Ricerche sul genere Alopecosa Simon (Araneae-Lycosidae) // Atti Soc. tosc. Sci. nat. Serie B. Vol.76. P.1-100.

Mcheidze T.S. 1997. [Spiders of Georgia: Systematics, Ecology, Zoogeographic Review]. Tbilisi University. 390 p. [in Georgian].

Mikhailov K.G. 1997. Catalogue of the spiders (Arachnida, Aranei) of the territories of the former Soviet Union. Moscow: Zoological Museum of the Moscow State University. 416 p.

Nosek A. 1905. Araneiden, Opilionen und Chernetiden // Ann. naturhist. Hofmuseums. Bd.20. P.114-154.

Platnick N.I. 2010. The world spider catalog, version 10.5. American Museum of Natural History, online at http://research.amnh. org/entomology/spiders/catalog/index.html

Reimoser E. 1919. Katalog der echten Spinnen (Araneae) des Palaarktischen Gebietes // Abh. zool.-bot. Ges. Wien. Bd.10. H.2. S. $1-280$.

Schmidt P. 1895. Beitrag zur Kenntniss der Laufspinnen (Araneae Citigradae Thor.) Russlands // Zool. Jahrb., Abt. Syst., Geogr. u. Biol. Bd.8. S.439-484.

Song D. X., Zhu M. S., Chen J. 1999. The Spiders of China. Shijiazhuang: Hebei Science and Technology Publishing House. $640 \mathrm{p}$.

Spassky S.A. 1927. [Contributions a la faune des araignees de la Tauride] // Izvestiya Donskogo Instituta selskogo khozyaistva i 


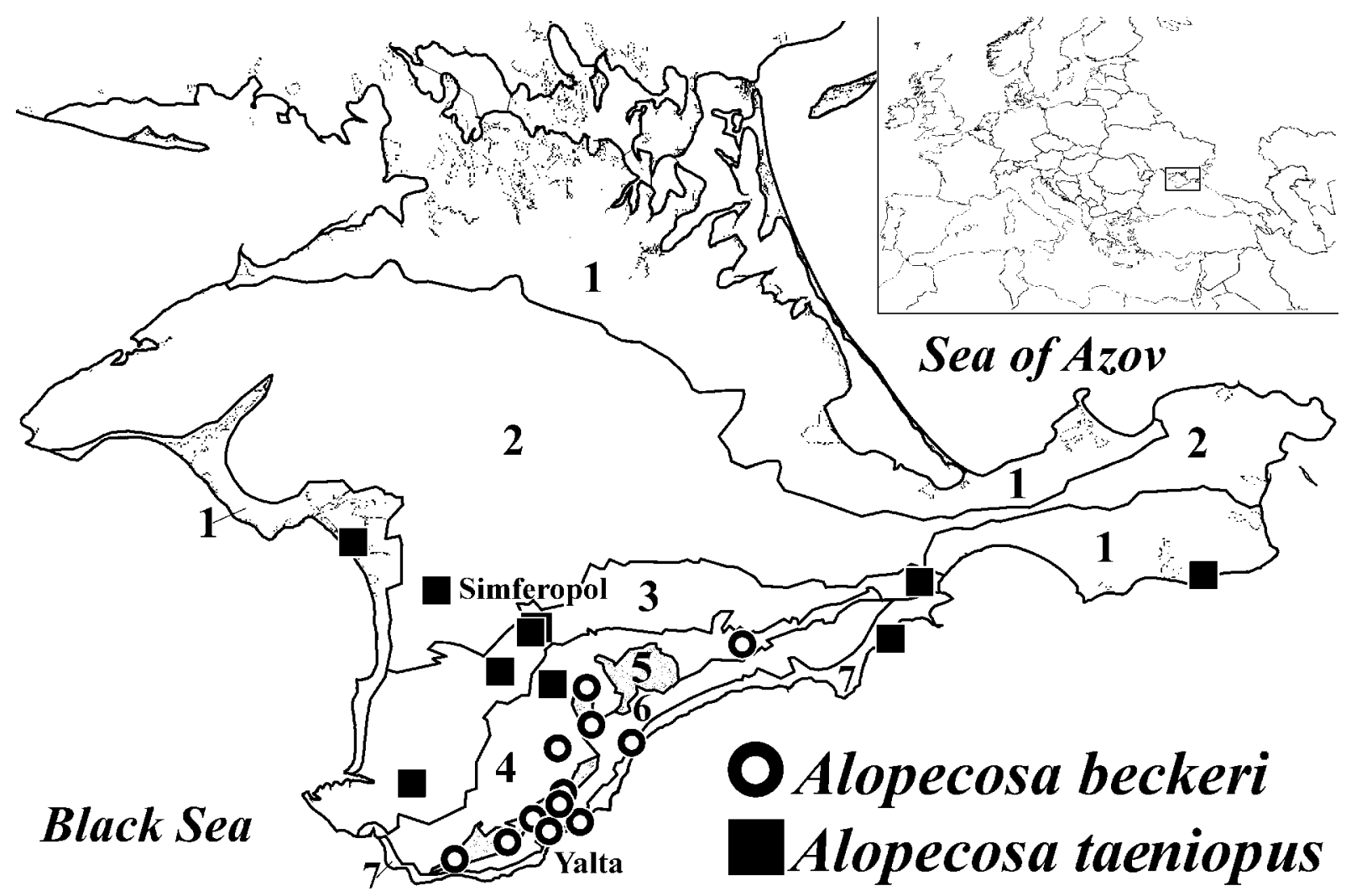

Map 1. Landscape distribution of Alopecosa beckeri and A. taeniopus in Crimea.

Карта 1. Ландшафтное распределение Alopecosa beckeri и A. taeniopus в Крыму.

melioratsii. Vol.7. P.66-80 [in Russian].

Thorell T. 1875a. Verzeichniss sudrussischer Spinnen // Horae Societatis entomologicae Rossicae. T.11. P.39-122.

Thorell T. 1875b. Descriptions of several European and North African spiders // Kongl. Svenska Vetenskaps-Akademiens Handlingar. Bd.13. No.5. P.1-203.
Tyshchenko V.P. 1971. [An identification guide to the spiders of the European part of the USSR]. Leningrad: Nauka. 281 p. [in Russian].

Responsible editor Yu. Marusik 